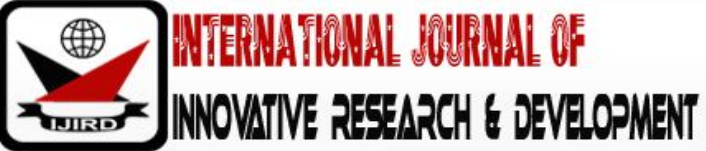

ISSN 2278 - 0211 (Online)

\section{Real-Time Synthetic Conversion of the Entire Flared Associated Natural Gas Stream to Liquefied Petroleum Gas (LPG)}

\author{
Dr. Azunna I.B. Ekejiuba \\ Senior Lecturer, Department of Petroleum Engineering, Federal University of Technology Owerri, Nigeria
}

\begin{abstract}
:
About 1,000 scf of gas is produced with every barrel of oil produced in Nigeria which implies that about 2.8 billion scf of associated gas is produced daily, based on the OPEC allowed 2.8 million barrels per day (bpd). At present, about $50 \%$ of the associated stranded natural gas produced in Nigeria is still being flared, that is 1.4 billion scf $(30,960.974$ tons or 30,960,974 $\mathrm{kg}$ of LPG equivalent on conversion)daily. On the other hand, Nigeria's annual consumption of LPG is expected to be 2.0 million metric tons this 2018 while 11.3 million metric tons (30,960.974 x365 tons $=11,300,755.51$ tons or 11,300,755,510 kg) can be produced annually from the entire flared gas. The major components of LPG (propane and butanes) hydrocarbons are gaseous at normal atmospheric temperature $\left(20^{\circ} \mathrm{C}\right)$ and pressure $(14.7 \mathrm{psia}, 0 \mathrm{psig})$, but are readily liquefied through pressurization (by compression) at relatively moderate pressures less than $200 \mathrm{psig}$ at room temperature $\left(25^{\circ} \mathrm{C}\right)$, leading to volume reduction from $270 \mathrm{scf}$ of gas to 1 cubic feet of liquid, which implies that the flared 1.4 billion scf in gaseous form will reduce to approximately 5.2 million cubic feet in liquid form. The investigation on the real-time Synthetic Conversion of the Entire Flared Association Gas Stream to liquefied Petroleum Gas (LPG) is focused on the use of customized skid mounted mini gas liquefaction plants aimed at cracking the $\mathrm{C}_{5}+$ fractions to the lighter molecules of $\mathrm{C}_{3}$ and $\mathrm{C}_{4}$ as well as steam reforming the $\mathrm{C}_{1}$ and $\mathrm{C}_{2}$ fractions to the heavier molecules of $\mathrm{C}_{3}$ and $\mathrm{C}_{4}$. The approach is based on the fact that it is technically feasible to synthesize almost any hydrocarbon from any other using chemical transformation operations to change the proportions of the hydrocarbons contents. The actual hydrocarbons percentage in typical flare line is $97.61 \%$, and for the 20 million scfd flare stream it is equivalent to $19,522,000 \mathrm{scfd}$, that is 442.300 tons or $442,300 \mathrm{~kg}$ of LPG daily. Assuming that $20 \%$ of the chemical energy of the entire flare stream is released as heat energy in the process, it implies that $80 \%$ of the hydrocarbon component of the flare stream is available for conversion to LPG daily i.e. $(442,300 \times 0.8)=353,840 \mathrm{~kg}$. Annually it is equivalent to 442.300 x 365 tons (161,439.5 tons or 161,439,500 kg). Currently there are about 350 bottling plants while to saturate the market with LPG the country needs about 2000 bottling plants. The LPG producible from the countries flared stranded gas, will be is sufficient to saturate the Nigerian market with LPG, drastically reducing the retail price of LPG that is presently hinged on the NLNG international market fundamentals as well as improve on Nigeria's per capita usage of LPG which is currently ranked the lowest in Sub-Saharan Africa. LPG is a group of flammable hydrocarbon gases that are commonly used as fuel in heating appliance, cooking equipment, vehicles, as well as for refrigerant, aerosol propellants and petrochemical feedstock. Although each of the specifications of LPG (commercial propane, commercial butane, is o butane, mixture of propane- butane) have some areas of preference, based on their different physical properties, any device that is suitable for any of the LPG category, would also be suitable for the others, primarily by adjustments on the maximum flow rate, to adopt to the maximum output of the device. Due to the strong quest for cleaner energy and numerous petrochemical/ chemical products from methane, ethane, propane and butanes, the world is presently witnessing rapid transition from the "gasoline age" to what might be called "LPG/ methane age or methane economy".
\end{abstract}

Keywords: Customized skid mounted mini gas liquefaction plants, liquefied petroleum gas, methane economy, real-time synthetic conversion

\section{Introduction:}

Nigeria produces petroleum (crude oil and natural gas) from her Onshore and Offshore Shallow water in the Niger Delta and Offshore Deep waters. The operators are Nigerian National Petroleum Corporation (NNPC), in partnership with 5 majors - Shell Petroleum Development Company (SPDC), ExxonMobil, Chevron, Eni-Agip and Total with their respective affiliates; 30 independents and local operators, 36 marginal field operators, 84 on licensing rounds 2005, 2006, and 2007 operators/ partners, and 18 on Nigeria/ Sao Tome and principle Joint Development operators. The Niger Delta onshore has only been explored and exploited to a depth of approximately 3,600m (12,000ft). New discoveries below 3,600m onshore Niger Delta, by both SPDC and Chevron indicategood potential for oil at greater depths. In Nigeria, according to SPDC, on the average, about 1,000scf of gas is produced with every barrel of oil, thus with 2.8 million barrels per day (bpd) about 2.8 billion scf associated gas is produced daily (Malumfashi, 2007).

Research conducted jointly at the Technical University of Munich and Dow Chemical Company (Johannes A. Lercher) explain that $30 \%$ to $60 \%$ of the world's natural gas is classified as 'stranded' meaning that it cannot be used locally or 
transported economically to other markets when produced in the course of pumping crude oil, and such gas is vented to atmosphere or burned, figure 1, at either the wellhead, flow- stations, refineries, et cetera.

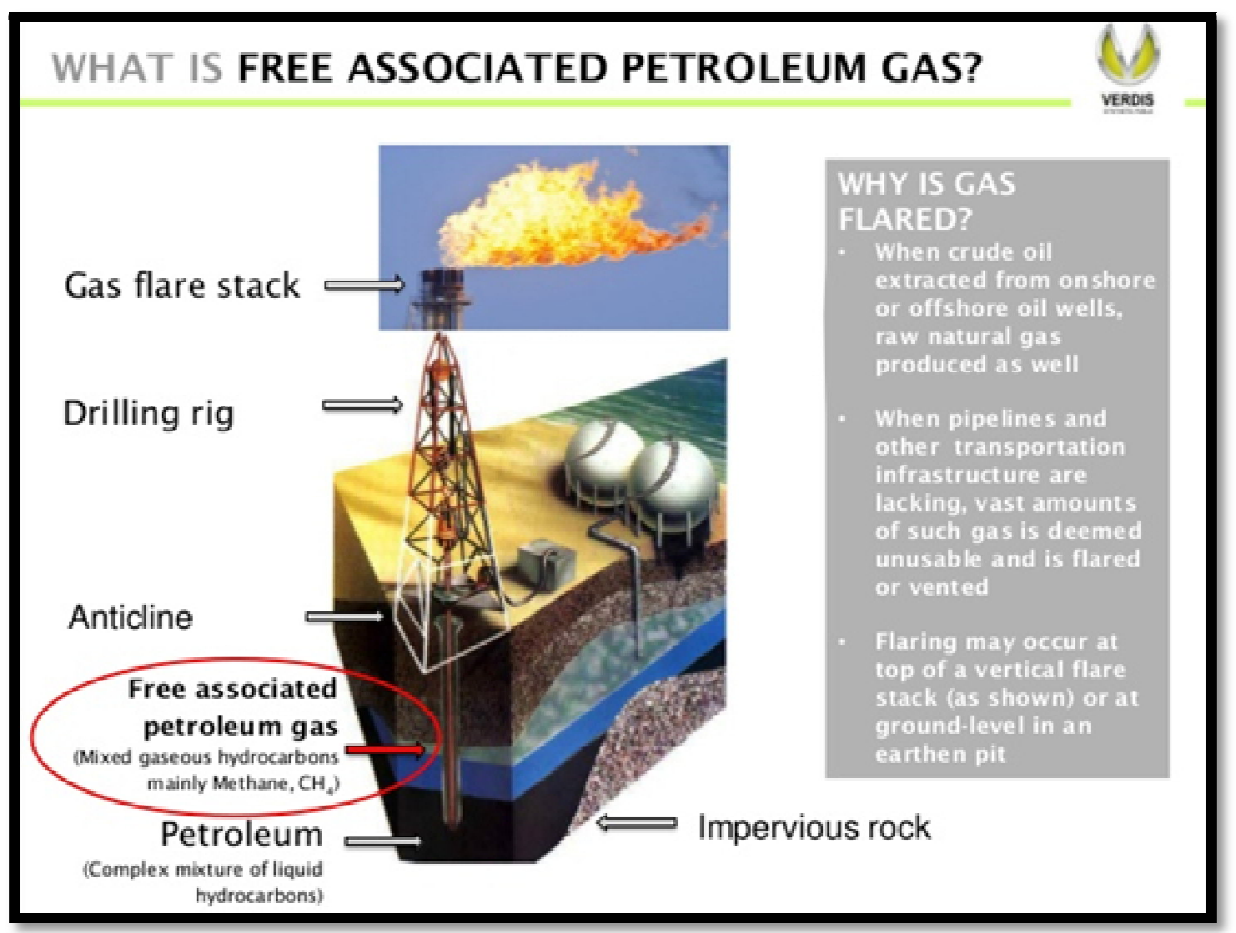

Figure 1: Natural Gas Flare Process from the Source (Reservoir) to the Stack Flame Source: Adapted From Images of Flared Natural Gas

\subsection{Flaring of the Associated Natural gas}

Associated gas flaring has been a major problem in the oil world. It dates back to the very first production well and is still a common and continuous exercise despite the huge amount of revenue lost as a result of this practice. The wasted associated stranded natural gas is mainly methane, a compound in great demand as chemical feedstock, commercial and industrial products, gas-to-methanol (GTM), liquefied natural gas (LNG), et cetera. When the associated stranded natural gas contains substantial amount of ethane and the higher paraffin homologues (i.e. ethane, propane, butanes and natural gasoline 'pentanes and heavier hydrocarbons'), as in the case of Nigeria, these are extracted (removed) from the gas stream for additional processing, because the resultant 'natural gas liquids NGLs' have high market values as liquefied petroleum gas (LPG), gasoline blending stock and petrochemical/ chemical plant raw material feedstock. The LPG component, which is about $10 \%$ of the total gas mixture (figure 2), can be used as a mixture (composed of primarily propane, butane and isobutane) or separately as propane, butane and iso-butane liquefied gases, figure3.

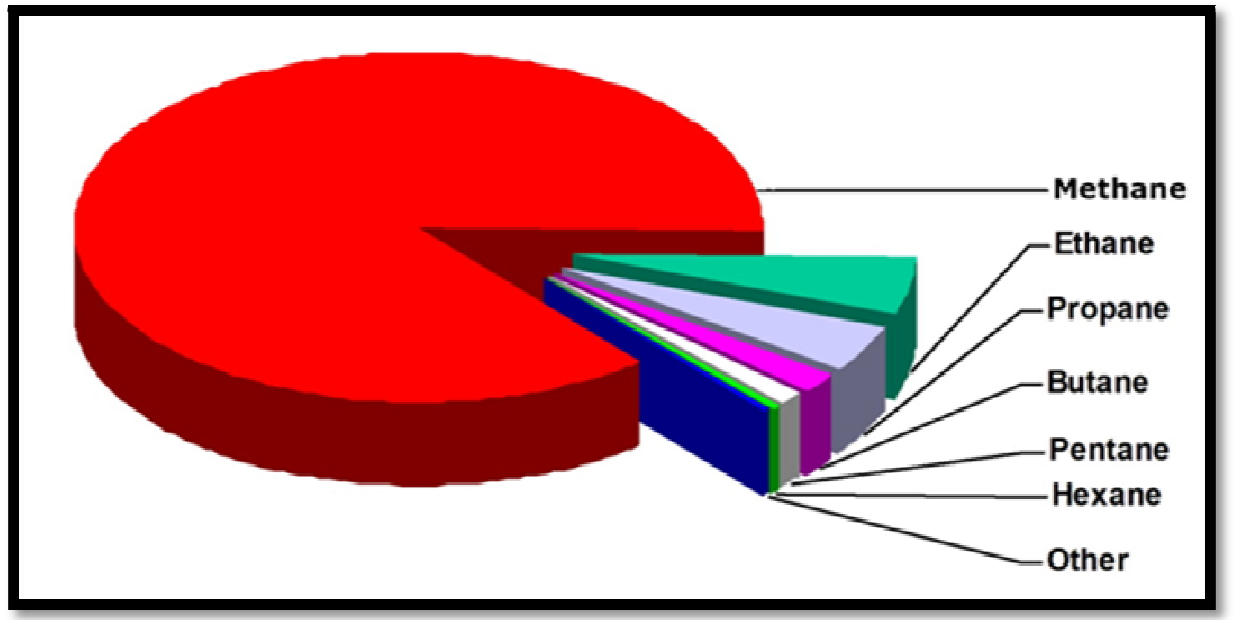

Figure 2: Components of Gas Mixture

Source:Adapted from images of natural gas composition 


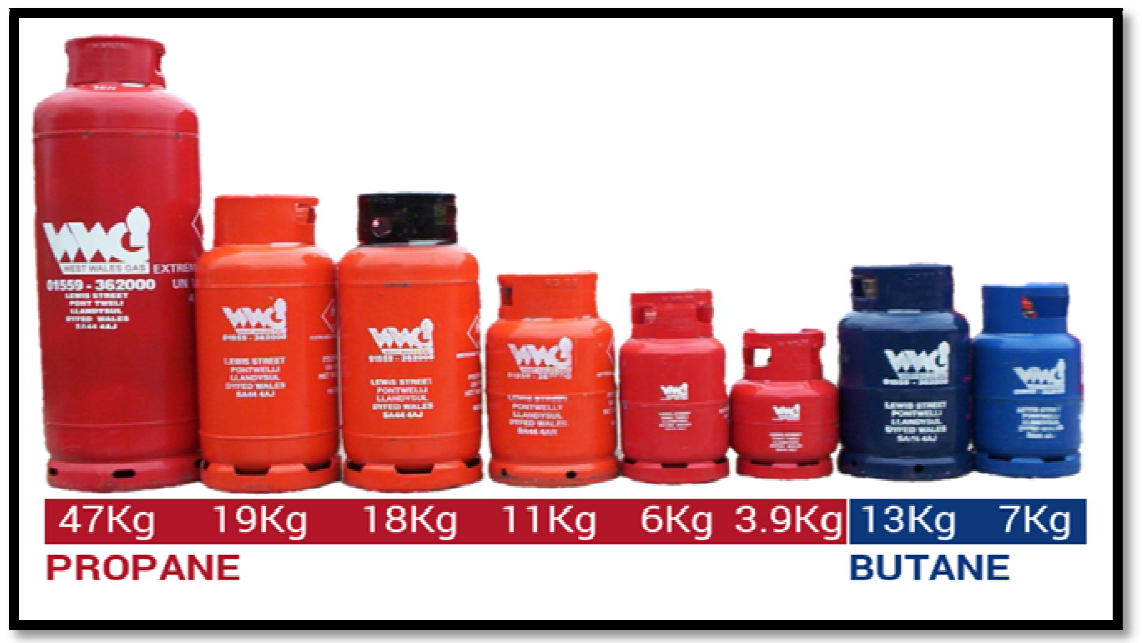

Figure 3: Various LPG Cylinder Sizes

Source: Adapted From Images of LPG Cylinder Sizes

\subsection{LPG Discovery}

The use of petroleum spread slowly in what has been called the "Kerosene Age" 1859-1900 (Levorsen, 1967), because, although petroleum products were also largely used for lubricants, the main aim of refining crude oil then was to produce kerosene $\left(\mathrm{C}_{12}-\mathrm{C}_{16}\right)$ for lamp oil (illuminating fuel). Then $\mathrm{C}_{11}-\mathrm{C}_{1}$, comprising (gasoline, methane et cetera) was regarded as waste product and was flared off. Kerosene was first distilled from bituminous Coal (Nova Scotia coal) and oil shale experimentally in 1846 (Clark, 1963), by Abraham Gesner, a Canadian geologist residentin Pittsburgh America. Subsequently, in 1851, Samuel Martin Kier began selling lamp oil which he distilled from crude oil, to local miners under the name "carbon oil". By 1852, the increased supply of petroleum allowed oil refiners to entirely side-step the oil-fromcoal, for illuminating oil from petroleum. Commercial production of kerosene started in 1854 and the petroleum-based illuminating oil was widely sold as kerosene. Due to the development of the Internal Combustion Engine near the beginning of the twentieth century, gasoline became the chief product being derived from petroleum, leading to what might be called the "gasoline age". The initial gasoline sold, comprised $\mathrm{C}_{3}-\mathrm{C}_{11}$ distillate from the crude oil, which resulted to rapid evaporation/ consumption in the internal combustion engine, until 1910 when Dr. Walter O. Snelling an American Chemist and explosive expert with US Bureau of mines, while researching on the properties of petrol (gasoline), separated gaseous fractions from liquid ones, thus discovering the existence of propane, hence LPG. LPG is gaseous at normal temperature and pressure, but liquefies readily under moderate pressures less than 200psig at room temperature. It expands to 270 times the volume when it goes from liquid to gas figure 4 .

LPG Gaseous Expansion

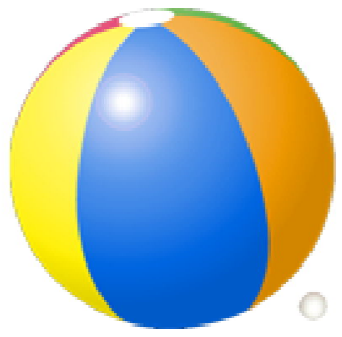

LPG expands to 270 times the volume when it goes from liquid to gas

Figure 4: LPG Volume Change from Gas to Liquid

Source: Adapted From Images of LPG Gaseous Expansion

The present petrol (gasoline)/ naphtha is comprised of $\mathrm{C}_{5}-\mathrm{C}_{11}$, while the world is witnessing rapid transition from the "gasoline age " to what might be called "LPG/ methane age or methane economy" due to the strong quest for cleaner energy and numerous petrochemical/chemical products from methane, ethane, propane and butane $\left(\mathrm{C}_{1}\right.$ to $\mathrm{C}_{4}$ hydrocarbons). Presently the overall products from the petroleum refining are usually grouped into four Categories: light distillates (LPG, Gasoline, and Naphtha); middle distillates (kerosene, jet fuel, and diesel); heavy distillates and residuum (heavy fuel oil, lubricating oils, wax, asphalt, figures 5 . The Fuel Gas comprising methane $\left(C_{1}\right)$ and ethane $\left(C_{2}\right)$ are generally not marketable; rather it is either used as fuel for refinery heaters/ furnaces or flared. 


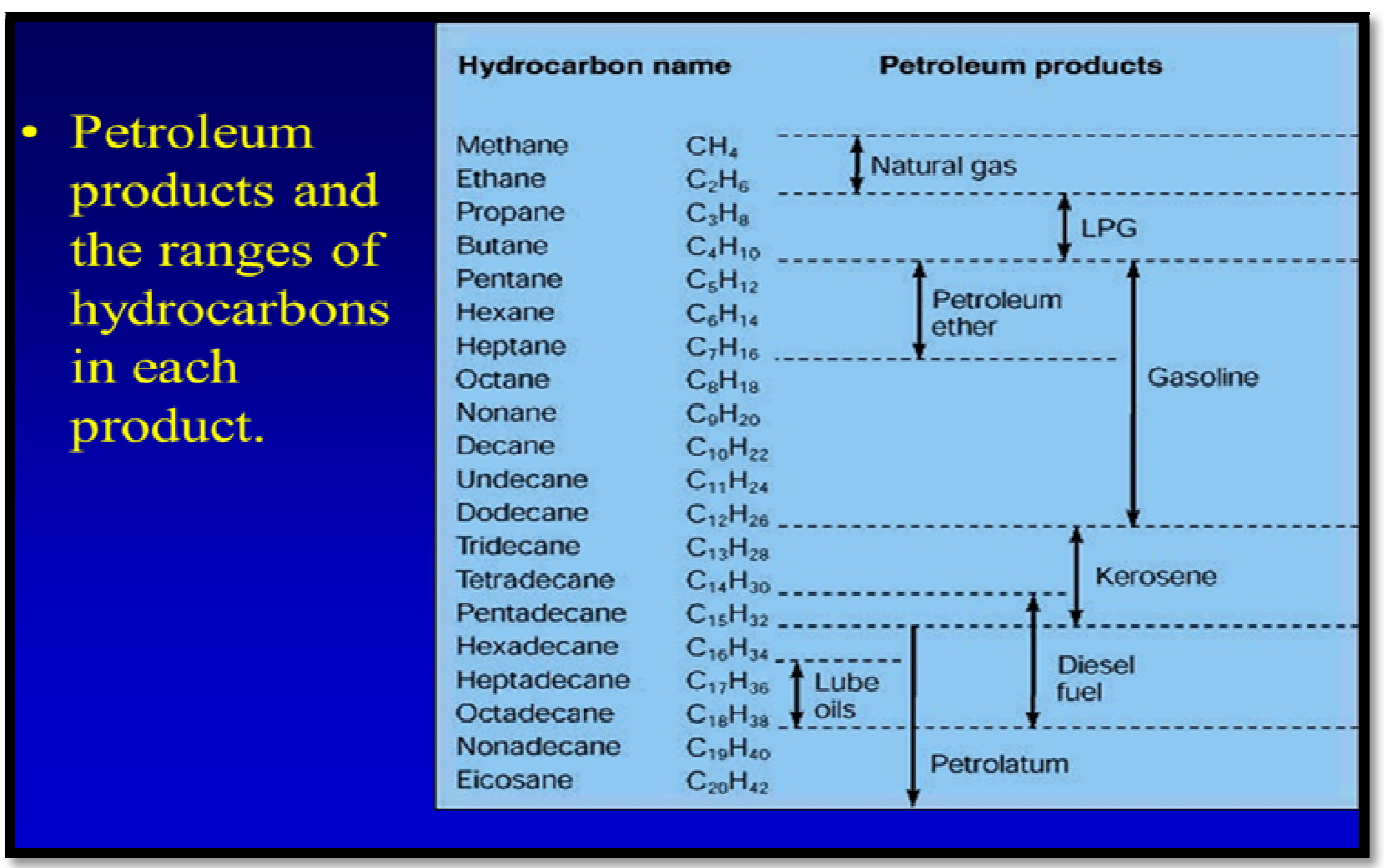

Figure 5: Basic Petroleum Refinery Products

Source: Adapted from Images of the Hydrocarbon Chemistry

\subsection{LPG Production and Consumption in Nigeria}

Production of LPG in Nigeria started with the premier oil refinery, built and commissioned in 1965 at Port Harcourt with maximum capacity of 60,000 bpd of refined products. The designed product slate from the current four refineries are white products-liquefied petroleum gas (LPG); Regular and Premium Gasoline \{Regular Motor Spirit (RMS)Super petrol and Premium Motor Spirit(PMS)\}; Kerosene \{Dual Purpose Kerosene(DPK)-illuminating kerosene and Aviation Treatment Kerosene (ATK) \}; Light Gas Oil \{Automotive Gas Oil (AGO)-diesel\}; Heavy Gas Oil and Lubricating Oil \{Fuel Oil in two grades- low pour fuel oil (LPFO) and high pour fuel oil (HPFO) \}; Residue\{Asphalt/ Bitumen, Base Oils/ Lube Base, Paraffin Wax $\}$ and sulphur. Presently as a result of various problems with the different refineries, they are all under refurbishment and the country have relied on importation for more than 75 percent of petrol products it uses, for well over 15 years now (Okafor, 2015). On the 23rd Jan. 2017, the Federal Government told International oil companies (IOC's) operating in the country to invest on building refineries on direct sales model to recoup the investment within a short period (Obosi, Eboh, 2017).

From 1965 to 2007 the Country relied on the refineries and importation for her LPG needs until Nigerian Liquefied Natural Gas (NLNG) Company intervened in 2007, through 21 off-takers saddled with the responsibility of distributing the product to the local market as NLNG is not established for local distribution of LPG. Nigeria's annual consumption of LPG has grown from 130,000 metric tons in 2011; 145,000 metric tons in 2012; 250,000 metric tons in 2013; to 500,000 metric tons in 2016 with a potential to hit 2,000,000 metric tons in 2018 (Uwandu, 2017). Meanwhile Nigeria is ranked the lowest in Sub-Saharan Africa in per capita usage of LPG, in consuming $1.8 \mathrm{~kg}$ compared with Ghana at $3.0 \mathrm{~kg}$, South Africa $5.5 \mathrm{~kg}$ and Morocco $44 \mathrm{~kg}$. Currently there are about 350 bottling plants while to saturate the market with LPG the country needs about 2000 bottling plants. On the other hand, the price of LPG is hinged on the NLNG international market fundamentals, which has always maintained the retail price of $12.5 \mathrm{~kg}$ cylinder between $\$ 14$ to $\$ 18$, equivalent of $\$ 400$ to $\$ 5500$ at the $2017 / 2018$ exchange rate of $\$ 1=\$ 305$. This also translates to $\$ 0.65$ per liter of LPG in Nigeria. The price LPG per liter in some other African countries is as follows: South Africa (\$0.96), Kenya (\$1.69), Togo (\$0.51), Ghana (\$0.79), etc. while the global average is ( $\$ 0.58)$.

\subsection{Study Significance}

Presently, Nigeria still flares around 50 per cent of its associated stranded natural gas, which could produce all the LPG for domestic consumption in the Country. Typically, the molecular constituents of alkanes in Natural gases ranges from methane to heptanes plus, and it is technically feasible to synthesize almost any hydrocarbon from any other using customized skid mounted mini gas liquefaction plants. This implies that the proposed technique is aimed at cracking the $\mathrm{C}_{5}$ +fractions to the lighter molecules of propane $\mathrm{C}_{3}$ and butanes $\mathrm{C}_{4}$ as well as steam reforming the $\mathrm{C}_{1}$ and $\mathrm{C}_{2}$ fractions to the heavier molecules of $\mathrm{C}_{3}$ and $\mathrm{C}_{4}$.This paper is aimed at evaluating the Real-Time Synthetic Conversion of the Entire Flare Associated Stranded Natural Gas Stream to Liquefied Petroleum Gas (LPG) based on their parameters, such as flow rate, gas composition et cetera. Processing the flared associated stranded natural gas for LPG will not only alleviate price dependent on international market fundamentals but also, drastically reduce the retail price to about 50 percent as well as generate power electricity, thereby creating numerous job opportunities in Nigeria.

\section{Background}

In the early days of the petroleum industry, the proportion of the different fractions of the crude oil separated/ obtained by distillation were solely dictated by the characteristics of the original crude oil, figures6. 


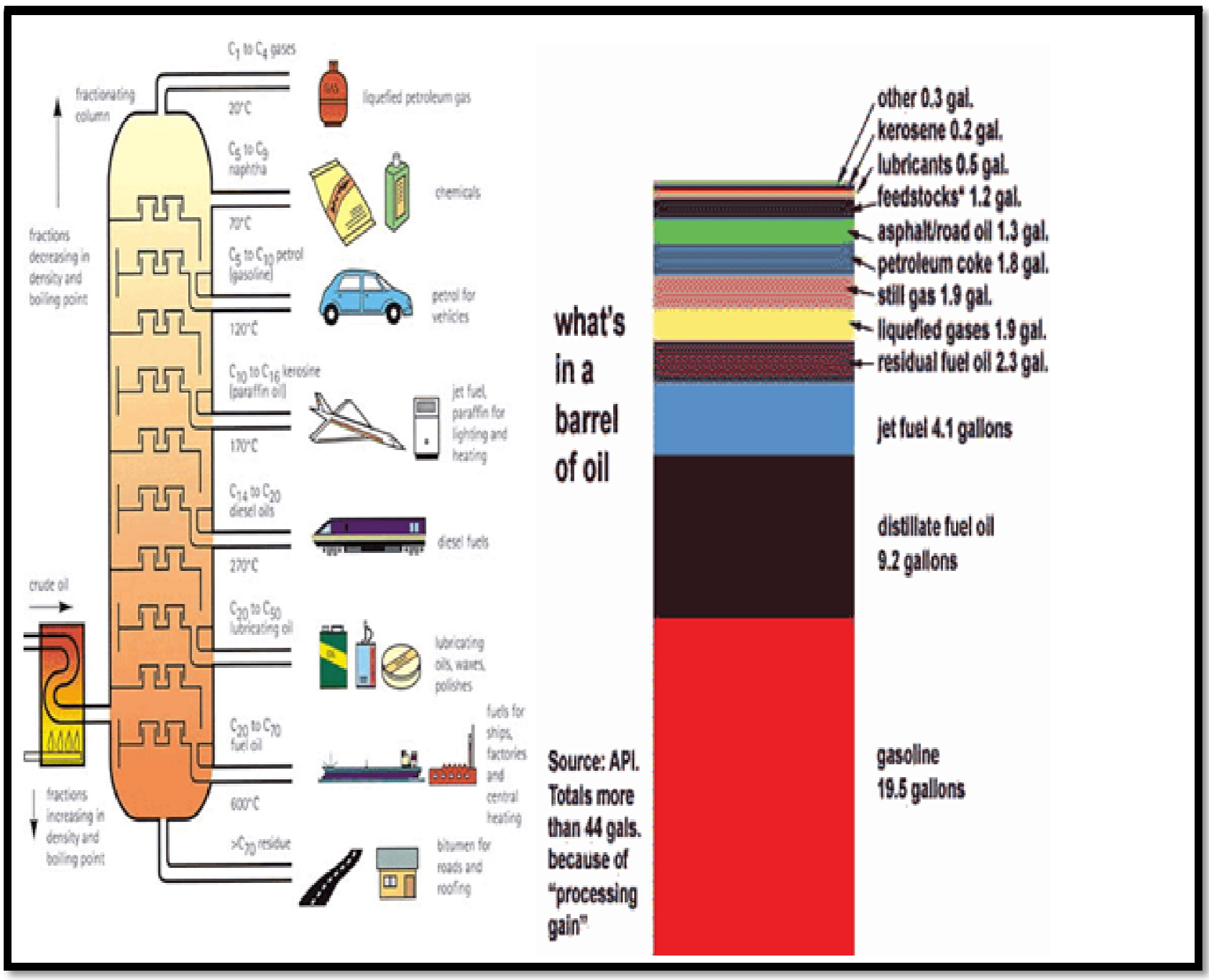

Figure 6: Various Products from Crude Oil

Source: Adapted from Images of Fractional Products from the Refinery

Presently, chemical transformation operations are used to change the proportions of the different hydrocarbons, such that, while some processes (i.e. cracking) are aimed at increasing the yield of lighter (valuable fractions $\mathrm{C}_{10}-\mathrm{C}_{1}$ ) from medium $\left(\mathrm{C}_{11}-\mathrm{C}_{20}\right)$ and residual cuts $\left(\mathrm{C}_{20}+\right)$, some other processes (i.e. steam reforming) are aimed at re-combining gaseous hydrocarbons $\mathrm{C}_{1}-\mathrm{C}_{4}$ to form heavier molecules of specific types in the gasoline boiling range $\mathrm{C}_{5}-\mathrm{C}_{10}$ and heavier. The three processes which give rise to important quantities of $\mathrm{C}_{3}-\mathrm{C}_{4}$ fraction (Hadley and Turner, 1973) are: Catalytic cracking, catalytic reforming and hydro cracking. Catalytic cracking yields propane, propylene, butanes and butenes while both catalytic reforming and hydro cracking yields propane and butanes (high iso/normal ratio). There feedstock is mostly middle distillates (kerosene, jet fuel, diesel) and heavy distillates (heavy gas oil) or residuum (residual fuel oil), such as heavy fuel oil, lubricating oils, wax, asphalt. Alternatively, $\mathrm{C}_{3}$ - $\mathrm{C}_{4}$ fractions are also produced from gaseous feedstock such as natural gas (methane) and ethane by steam reforming processes (to produce gaseous hydrogen and carbon monoxide otherwise known as syng as), which subsequently re-combined to selectively yield $\mathrm{C}_{3}-\mathrm{C}_{4}$ fractions.

\subsection{Chemistry of Cracking Reactions}

Crackingis the process whereby the chemical structure of heavier hydrocarbons (long-chain of hydrocarbons or of petroleum fractions) are changed, by heating under pressure (thermal cracking) or by heating in the presence of catalyst (catalytic cracking), into two or more lighter (short-chain) hydrocarbon molecules, figure 7. A fundamental difference exists between the two cracking, because the reactions proceed according to different mechanisms and consequently the end-products are different (Kings et al., 1973). 


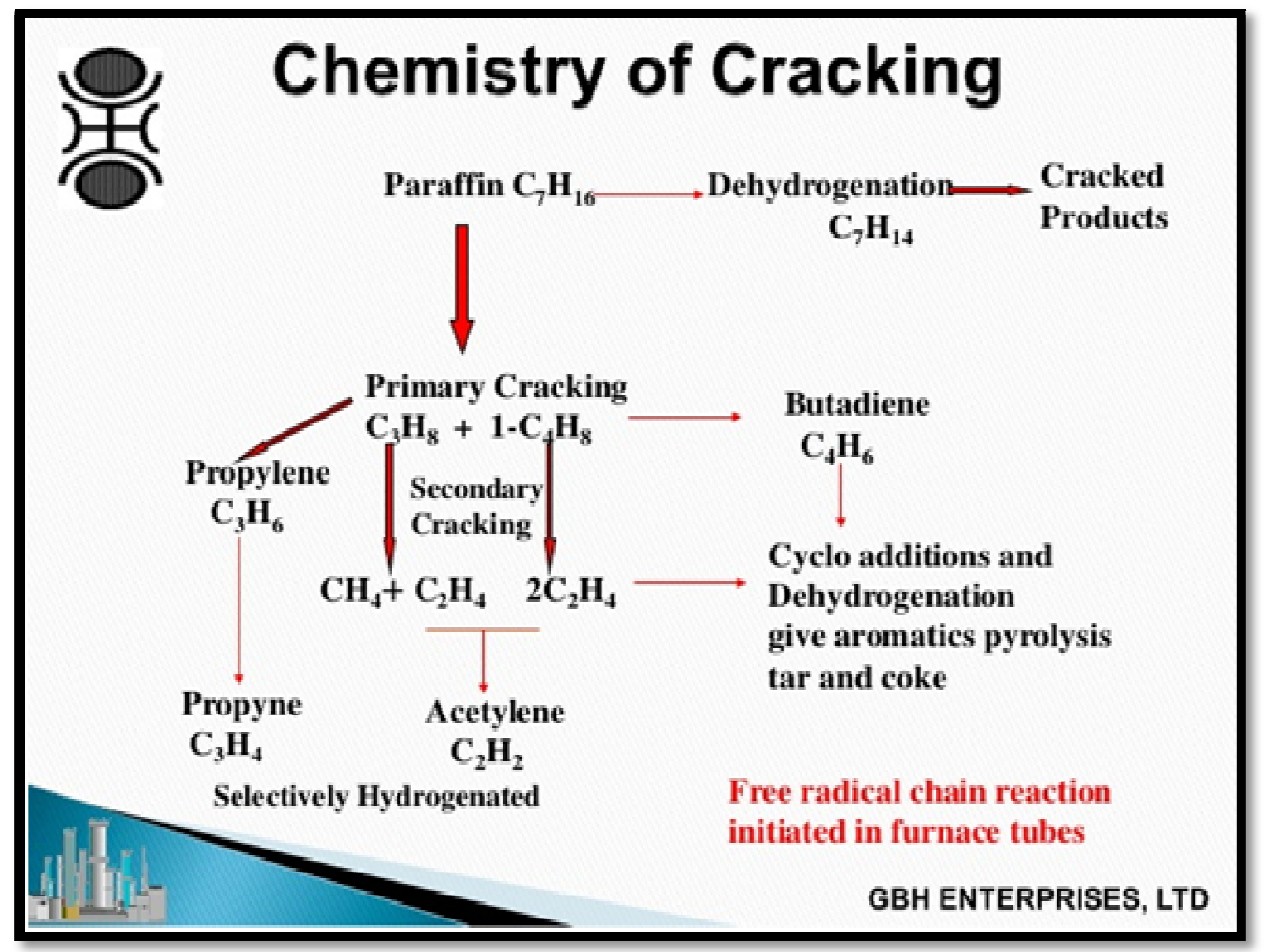

Figure 7: Hydrocarbon Cracking Process

Source: Adapted from GBH Enterprises, Ltd Images

In different industrial processes cracking reactions are based on the conditions (temperature, pressure, presence of catalyst etc.). The most important reactions occurring in both the thermal and catalytic cracking are $\mathrm{C}-\mathrm{C}$ bond scission, into the lighter paraffin and olefin, followed by dehydrogenation, isomerization and polymerization depending on the nature of the material being cracked (feed-stock charged) and the desired end-products. In catalytic cracking the bond rupture occurs at certain definite locations on the paraffin molecule, rather than randomly as in thermal cracking. Usually, catalytic cracking tends to yield products containing three- or four- carbon atoms rather than the one- and two- carbon atom molecules produced in thermal cracking. In catalytic systems normal paraffins cracks 5 to 60 times more rapidly than in non- catalytic systems while isoparaffins, catalytically crack more rapidly than the normal paraffins of the same molecular weight.

Hydrocracking is a catalytic cracking process assisted by the presence of hydrogen gas. In this process, the hydrocarbon stream is mixed with hydrogen and after heating and pressurization, the mixed vapors are passed over a bifunctional catalyst that is capable of rearranging and breaking hydrogen chains as well as adding hydrogen to aromatics and olefins to produce naphthenes andalkanes.Also, sulphur-, nitrogen-, and oxygen- containing compounds are hydrogenated to saturated hydrocarbons (kings et al., 1973). The products of this process are saturated hydrocarbons; depending on the reaction conditions (temperature, pressure, and catalyst activity) these products range from ethane, LPG to heavier hydrocarbons consisting mostly ofisoparaffins.

\subsection{Chemistry of Reforming Reactions}

Reforming is the process whereby the chemical structures of lighter hydrocarbons are changed, by heating under pressure (thermal reforming) or by heating in the presence of catalyst (catalytic reforming). The basic catalytic reforming processing step is directed at the production of motor spirit (gasoline) from naphtha and middle distillates in the series of processes commercialized as platforming, powerfoming, catforming ultra forming etc. (Lom, 1973). In these processes paraffinic and naphthenic hydrocarbons, in the presence of hydrogen and a catalyst are converted to liquid hydrocarbons (gasoline) of higher octane number and substantial quantities of hydrocarbon tail gases from methane to butanes (but mostly propane, n-butane and isobutane).On the other hand, steam reforming is a method of producing gaseous hydrogen and carbon monoxide (otherwise known as syngas), from natural gas and other saturated hydrocarbon (alkanes) such as ethane, propane, butane, pentane, hexane and heptanes plus, equations 1 to 3(Wikipediasteam reforming, n.d), which can subsequently be re-combined to selectively yield paraffin hydrocarbons (alkanes), water and heat (electricity), equation 4.
$\mathrm{C}_{\mathrm{n}} \mathrm{H}_{(2 \mathrm{n}+2)}+\mathrm{nH}_{2} \mathrm{O}$
$\longleftrightarrow$
$(2 \mathrm{n}+1) \mathrm{H}_{2}+\mathrm{nCO}$
$\mathrm{CH}_{4}+\mathrm{H}_{2} \mathrm{O}$

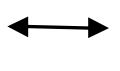
$3 \mathrm{H}_{2}+\mathrm{CO}$ (endothermic $+206 \mathrm{KJ} /$ mole)
Ethane:
$\mathrm{C}_{2} \mathrm{H}_{6}+2 \mathrm{H}_{2} \mathrm{O}$

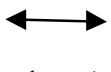
$5 \mathrm{H}_{2}+2 \mathrm{CO}$
$\mathrm{nCO}+(2 \mathrm{n}+1) \mathrm{H}_{2} \longleftrightarrow \mathrm{C}_{\mathrm{n}} \mathrm{H}_{2 \mathrm{n}+2}+\mathrm{nH}_{2} \mathrm{O}+$ heat (electricity)
syngas paraffin hydrocarbons water of synthesis 
Where " $n$ " is a positive integer, the simplest of these $(n=1)$ results in the formation of methane. Process condition and composition are usually chosen, with the help of selectivity catalysts, targeted at market demand to favor higher order reaction $(n>1)$. Generally, the temperature, pressure and catalyst determine the direction of the three chain growth reactions occurring at the same time with syngas. The first product direction involves dissociation (splitting) carbon monoxide $\mathrm{CO}$ into $\mathrm{C}$ and $\mathrm{O}$, after which $\mathrm{C}$ - atoms hydrogenate to $\mathrm{CHx}$ species and subsequently couple to longer hydrocarbon as follows:
$\mathrm{C}+\mathrm{H}$
$\mathrm{CH}+\mathrm{H}$
$\mathrm{CH}_{2}+\mathrm{H}$
$\mathrm{O}+\mathrm{H}$

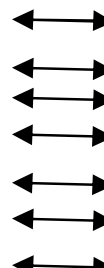
$\mathrm{CH}$
$\mathrm{CH}_{2}$
$\mathrm{CH}_{3}$
$\mathrm{OH}$
$\mathrm{OH}+\mathrm{H}$
$\mathrm{H}_{2} \mathrm{O}+\mathrm{CO}$
$\mathrm{H}_{2} \mathrm{O}$
$2 \mathrm{CO}$
$\mathrm{H}_{2}+\mathrm{CO}_{2}$
$\mathrm{CO}_{2}+\mathrm{C}$ (leading to deposition of carbon in the reactor tubes)

That is, the syngas is converted to hydrocarbons building blocks $\left(-\mathrm{CH}_{2}-\right)$ or hydrocarbons chain extension in presence of a catalyst which can produce different compounds of hydrocarbons (liquids) via polymerization of the hydrocarbon building block, figure 8 and about 20 percent of the chemical energy is released as heat.

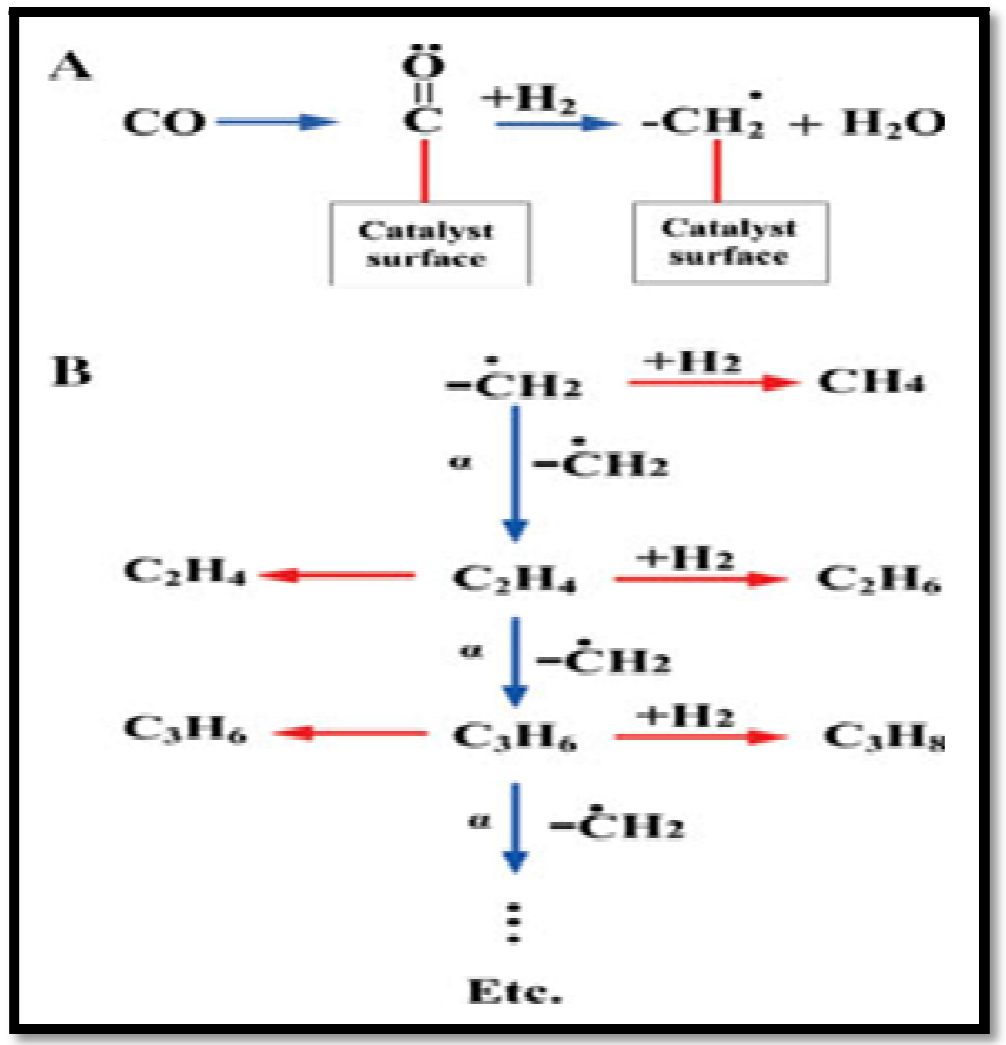

Figure 8: Synthesis Gas Conversion Alkanes Process

Source: Adapted From Images of Syngas to Alkanes

For the production of all LPG from the flare gas stream, catalytic cracking is used to split the $\mathrm{C}_{5}+$ fractions (captured in their vapor form or as natural gas liquids NGLs) to the lighter molecules of $\mathrm{C}_{3}$ and $\mathrm{C}_{4}$ i.e. liquefied petroleum gas (LPG). The main reactions involved in hydrocracking consist of those of catalytic cracking and isomerization, combined with the full hydrogenation of the cracked products. While steam reforming is used to chains i.e. bind the $\mathrm{C}_{1}$ and $\mathrm{C}_{2}$ fractions (captured in their vapor form or as liquefied natural gas $\mathrm{LNG}$ ) to the heavier molecules of $\mathrm{C}_{3}$ and $\mathrm{C}_{4}$. The process conditions are usually chosen with selectivity catalyst that are targeted to favor and maximize the formation of propane $\mathrm{C}_{3}$ and butanes $\mathrm{C}_{4}$.

\section{Material}

Table 1 shows the typical representative composition of the flared associated stranded natural gas stream in Nigeria, obtained from statistical analysis of 36 flare streams, selected from 150 flare line data samples. And table 2 contains the average operational parameters of the Nigeria flare gas stream. 


\begin{tabular}{|c|c|}
\hline Component & Mole \% \\
\hline Methane & 78.5375 \\
\hline Ethane & 7.7880 \\
\hline Propane & 5.9625 \\
\hline i-butane & 1.4842 \\
\hline n-butane & 1.8882 \\
\hline i-pentane & 0.6964 \\
\hline n-pentane & 0.4982 \\
\hline Hexane plus & 0.7550 \\
\hline Nitrogen & 0.1729 \\
\hline Carbon dioxide & 2.0105 \\
\hline Other undesirables & 0.2066 \\
\hline & 100.0000 \\
\hline
\end{tabular}

Table 1: A Typical Representative Composition of Flare Associated Stranded Natural Gas in Nigeria

Source: Adapted from Ekejiuba, 2017

\begin{tabular}{|c|c|c|}
\hline Parameter & Range & Value for the Study \\
\hline Gas Gravity (air) & 0.607 to 0.996 & 0.755 \\
\hline Flow rate MMscfd & 5 to 63 & 20 \\
\hline Pressure Psig & 7 to 75 & 10 \\
\hline Pressure & 21.7 to 89.7 & 25 \\
\hline Temperature F & 60 to 115 & 80 \\
\hline Base Temperature During Analysis & - & $60{ }^{\circ} \mathrm{F}$ \\
\hline Base Pressure During Analysis & - & $14.7 \mathrm{psia}$ \\
\hline
\end{tabular}

Table 2: Flare Conditions of the Associated Stranded Natural Gas in Nigeria Source: Adapted from Ekejiuba, 2017

\section{Model Application}

Figure 9, is the proposed design process layout for convertingthe entire hydrocarbons components of theflared associated natural gas to liquefied petroleum gas (LPG)

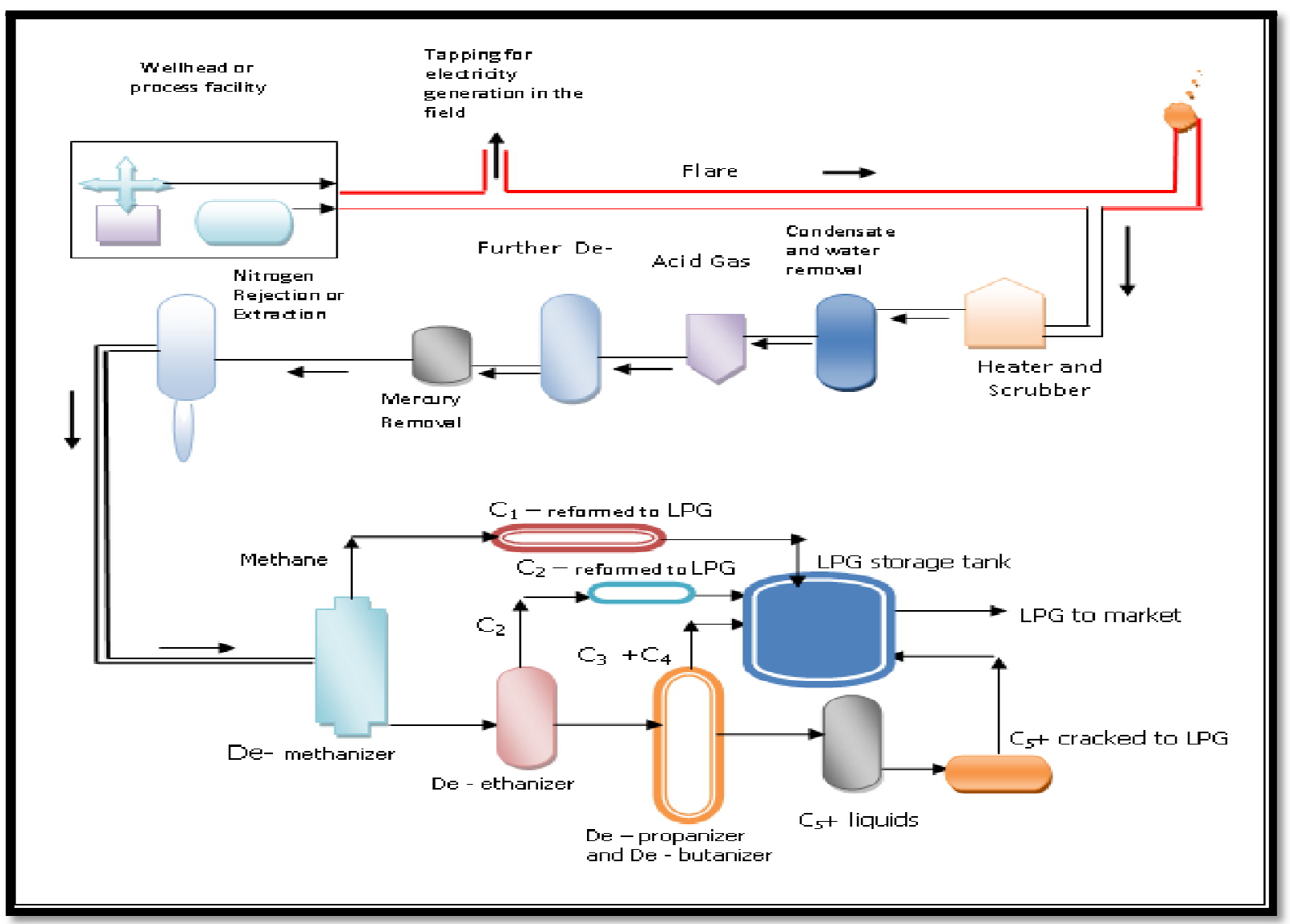

Figure 9: Process Layout for the Real-Time Conversion of the Flare Stream to LPG 


\section{Results and Discussion}

Since 1,000 scf of gas is produced with every barrel of oil produced in Nigeria it means that, about 2.8 billion scf of associated gas is produced daily based on the OPEC allowed 2.8 million barrels per day (bpd). Therefore, the $50 \%$ flared associated stranded natural gas produced in Nigeria, is equal to 1.4 billion scfd.

The total percentage of the hydrocarbons in the flare stream (table 1 ) is $97.61 \%$, which implies that, for the 20,000,000 scfd flare line, the actual hydrocarbons flare quantity is 19,522,000 scfd (i.e. 20,000,000 x 0. 9761), and for the overall flared gas in Nigeria, it is 1,366,540,000 scfd (i.e. 1,400,000,000 x 0.9761).

Natural gas reduces by 270 times the volume when it goes from gas to liquid (LPG), thus the 1.4 billion scf of gas flared daily in Nigeria is equivalent to 5,061,259.259 cubic feet in liquid (LPG) volume(i.e. 1,400,000,000 x 0.9761/270 $=5,061,259.259$ ). While the 20 million scfd flared by the typical flare line in Nigeria will yield 72,303.704 cubic feet liquid (LPG)volume (i.e.20,000,000x0.9761/ $270=72,303.704$ ).Although associated stranded flared natural gas is measured in either standard cubic feet $\left(\mathrm{ft}^{3}\right)$ or cubic meters $\left(\mathrm{m}^{3}\right)$, the liquefied petroleum gas (LPG) is usually sold in kilograms $(\mathrm{kg})$ bottles of $1.0 \mathrm{~kg}$ to $210 \mathrm{~kg}$, in pounds or in tons as Commercial propane, Commercial butane and Propane-butane mixture. This requires the conversion of the flare stream volume measurement in $\mathrm{ft}^{3}$ or $\mathrm{m}^{3}$ to weight equivalent in $\mathrm{kg}$, using the apparent molecular weight of the flare stream gas mixture $\left\{\mathrm{Ma}=\sum \mathrm{yiMi}\right\}$, table 3.

Where:

Ma = apparent molecular weight of mixture

yi $=$ mole fraction of component $\mathrm{i}$

$\mathrm{Mi}=$ molecular weight of component i

The molecular weight of a substance, also called the molar mass is the mass of 1 mole of that substance, given in grams. Molecular weight is represented by the same number in all unit systems ( $\mathrm{kg} / \mathrm{kmol}$. for SI system, Ib/ IbmoI. for English unit and g/ mol. for cgs unit).

The daily quantity of each component of the flare stream is obtained by multiplying the actual hydrocarbon flow rate with the fractional composition of the component. The daily flare quantity of each component is multiplied with the conversion factor 0.0283 to obtain the cubic meters equivalent.

For example, the daily flared quantity for methane is $19,522,000 \times 0.78537=15,331,993.14$.

And the cubic meters equivalent 15,331,993.14 x $0.0283=433,895.40$.

\begin{tabular}{|c|c|c|c|c|c|}
\hline Component & $\begin{array}{c}\text { Fractional } \\
\text { Composition } \\
\text { (yi) }\end{array}$ & $\begin{array}{l}\text { Daily Quantity } \\
\text { 19,522,000x yi } \\
\text { scfd rate }\end{array}$ & $\begin{array}{c}\text { Daily Cubic } \\
\text { meters'm }{ }^{3} \\
\text { (scfdx0.0283) } \\
\text { Equivalent }\end{array}$ & $\begin{array}{c}\text { Molecular } \\
\text { Weight g/ mol } \\
\text { (Mi) }\end{array}$ & $\begin{array}{c}\text { yiMi } \\
\text { g/mol }\end{array}$ \\
\hline Methane & 0.78537 & $15,331,993.14$ & $433,895.40$ & 16.04 & 12.597 \\
\hline Ethane & 0.07788 & $1,520,373.36$ & $43,026.57$ & 30.07 & 2.342 \\
\hline Propane & 0.05962 & $1,163,901.64$ & $32,9358.42$ & 44.09 & 2.629 \\
\hline i-butane & 0.01484 & $289,706.48$ & $8,198.69$ & 58.12 & 0.862 \\
\hline n-butane & 0.01888 & $368,575.36$ & $10,430.68$ & 58.12 & 1.097 \\
\hline i-pentane & 0.00696 & $135,873.12$ & $3,845.21$ & 72.15 & 0.502 \\
\hline n-pentane & 0.00498 & $97,217.56$ & $2,751.26$ & 72.15 & 0.359 \\
\hline Hexane plus & 0.00755 & $147,391.1$ & $4,171.17$ & 86.17 & 0.650 \\
\hline Total & & & & & 21.038 \\
\hline
\end{tabular}

Table 3: Apparent Molecular Weight of the Flare Stream Gas Mixture $\left\{\mathrm{Ma}=\sum\right.$ Yimi $\}$

- Scenario 1

(A) Applying the conversion from standard cubic feet (scf) to moles factor, (1 scf $=1.19804$ moles), the 19.522,000 scfd will yield 23,388,136.88 moles daily (i.e. 19,522,000 x 1.19804).

And since the apparent molecular weight of the gas mixture is $21.038 \mathrm{~g} / \mathrm{mol}$., the total weight of the equivalent LPG becomes:23,388,136.88 moles $\times 21.038 \mathrm{~g} / \mathrm{mol}$. $=492,039,623.68144$ grams $=492,039.624 \mathrm{~kg}$.

Assuming that $20 \%$ of the chemical energy of the entire flare stream is released as heat energy in the process, it implies that $80 \%$ of the flare stream is available for conversion to LPG daily i.e. $(492,039.624 \times 0.8)=393,631.6992 \mathrm{~kg}$.

(B) The possible electricity generation daily from the $20 \%$ released reaction heat is estimated as follows:

$19,522,000 \mathrm{scf} / \mathrm{d} \times 0.2=3,904,400 \mathrm{scf} / \mathrm{d}$

Dividing by 24 implies 3,904,400 / $24=162,683 \mathrm{scf} / \mathrm{h}$

For a Gas turbine generator with 30\% efficiency and applying the gas conversion assumed calorific value of $1000 \mathrm{Btu} / \mathrm{scf}$. The heat rate becomes $3412 / 0.3=11,373.33 \mathrm{Btu} / \mathrm{kWh}$.

Using the relation

Power Output $(\mathrm{kW})=\{$ Fuel Burned $(\mathrm{scf} / \mathrm{hr}) \mathrm{x}$ Heating Value Btu/ scf $\} /$ Heat rate Btu/ kWh

$=\{162,683 \times 1000 \mathrm{Btu} / \mathrm{scf}\} /\{11,373.33 \mathrm{Btu} / \mathrm{kWh}\}$

$=14,303.9022 \mathrm{~kW}$ 


\section{Approximately 14.3 MW}

\section{- $\quad$ Scenario 2}

From mathematical conversion table:

1 ton of $\mathrm{LPG}=1250 \mathrm{~m}^{3}$ of gaseous natural gas

$=1250 \times 35.31 \mathrm{ft}^{3}$ of gaseous natural gas

$=44,137.5 \mathrm{ft}^{3}$ of gaseous natural gas

For the entire 50 percent flared daily, this implies $(1,400,000,000 \times 0.9761 / 44,137.5)=30,960.974$ tons or 30 , $960,974 \mathrm{~kg}$ (for 1 ton $=1,000 \mathrm{~kg}=2,204.6$ pounds). The annually LPG becomes 30,960.974 x365 tons =11,300,755.51 tons or $11,300,755,510 \mathrm{~kg}$, While the 19,522,000 scfd for the typical flare line in Nigeria will yield $(19,522,000$ / $44,137.5)=442.300$ tons or $442,300 \mathrm{~kg}$ of LPG daily, which annually is equivalent to $442.300 \mathrm{x} 365$ tons $(161,439.5$ tons or $161,439,500 \mathrm{~kg}$ ).Assuming that $20 \%$ of the chemical energy of the entire flare stream is released as heat energy in the process, it implies that $80 \%$ of the hydrocarbon component of the flare stream is available for conversion to LPG daily i.e. $(442,300 \times 0.8)=353,840 \mathrm{~kg}$.

\section{LPG Value Chain / Uses}

LPG is not a by-product, rather it is actually an extremely versatile and valuable Co-products of both the Crude Oil Refinery distillation process and the natural gas sweetening process(figure 10).

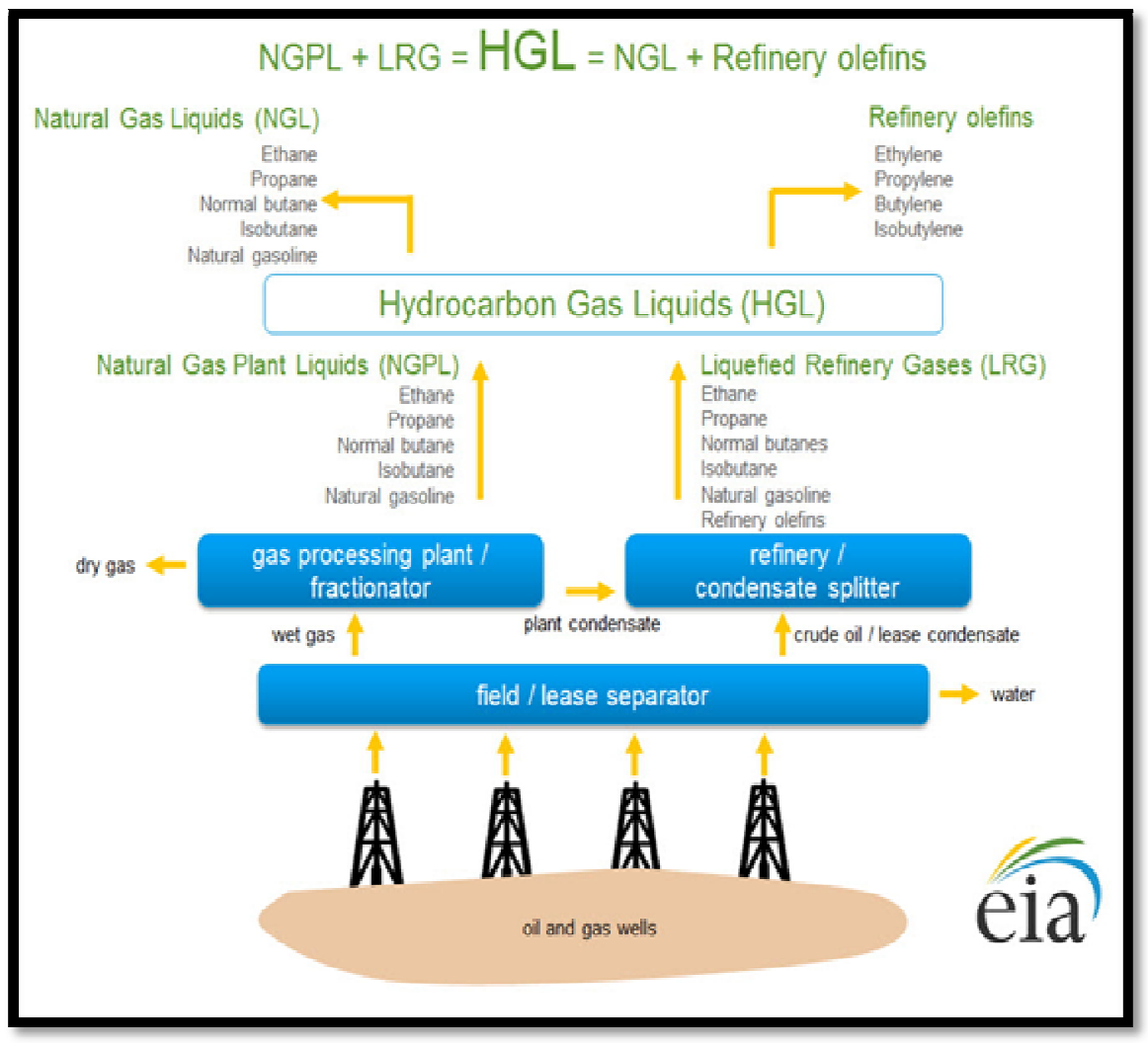

Figure 10: Sources of LPG Components

Source: Adapted From Images of the Composition of Natural Gas

LPG is a group of flammable hydrocarbon gases that are liquefied through pressurization (i.e. can be compressed into liquid at relatively low pressures) and commonly used as fuel in heating appliance, cooking equipment, vehicles, as well as for refrigerants, aerosol propellants and petrochemical feedstock (use in industrial, commercial, agricultural, horticultural and manufacturing applications).LPG can be used as a power source for combined heat and power (CHP) technologies. LPG can be converted intoalkylate which is a premium gasoline blending stock because it has exceptional anti-knock properties and gives clean burning. The gases that fall under the "LPG" label include propane, nbutane, i-butane or propane-butane blends, known as either commercial propane LPG, commercial butane LPG, and commercial propane-butane mixture LPG. Each of the above specifications have some areas of preference, based on their different physical properties Figure 11 and compositions Table 4, although any device that is suitable for any of LPG's category, would also be suitable for the others. Primarily the difference would be, adjustments on the maximum flow rate, to adapt to the maximum output of the device. 


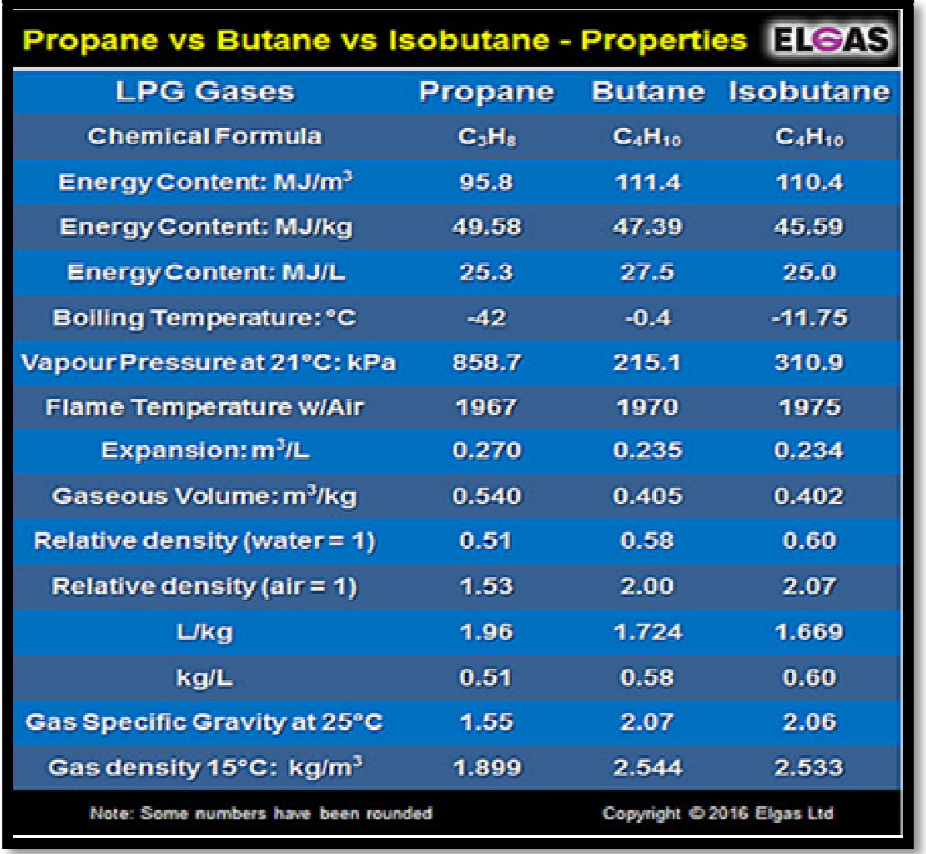

Figure 11: Different Physical Properties of the Various LPG Source: Adapted From Images of LPG Gaseous Expansion

\begin{tabular}{|c|c|c|c|}
\hline Composition, \% Vol. & $\begin{array}{c}\text { Commercial } \\
\text { Propane }\end{array}$ & $\begin{array}{c}\text { Commercial } \\
\text { Butane }\end{array}$ & $\begin{array}{c}\text { Propane-Butane } \\
\text { Mixture }\end{array}$ \\
\hline Ethane, $\mathrm{C}_{2}$ & 3.3 & $<0.1$ & 1.7 \\
\hline Propane, $\mathrm{C}_{3}$ & 92.5 & 13.5 & 53.0 \\
\hline $\mathrm{n}$-butane, $\mathrm{n}-\mathrm{C}_{4}$ & 1.0 & 49.5 & 25.3 \\
\hline i-butane, iso- $\mathrm{C}_{4}$ & 3.2 & 35.7 & 19.4 \\
\hline $\mathrm{n}$ - Pentane, $\mathrm{n}-\mathrm{C}_{5}$ & nil & 0.4 & 0.2 \\
\hline i - Pentane, iso- $\mathrm{C}_{5}$ & nil & 0.8 & 0.4 \\
\hline Hexane, $\mathrm{C}_{6}$ & nil & 0.1 & nil \\
\hline $\mathrm{H}_{2}$ Sppm & $<1$ & $<1$ & $<1$ \\
\hline Mercaptans, ppm & 2.4 & 1.8 & 2.1 \\
\hline Specific gravity,15.5/ 15.5 oC & 0.5135 & 0.5681 & 0.5488 \\
\hline Reid Vapor Pressure, psig & 234 & 96 & 205 \\
\hline Calorific Value, Btu/ Ib (Gross) & 21,500 & 21,200 & 21,350 \\
\hline Calorific Value, Btu/ Ib (Net) & 19,900 & 19,700 & 19,800 \\
\hline
\end{tabular}

Table 4: Some Typical LPG Composition and Properties in UK for Typical the Commercial Propane, Commercial Butane and Propane-Butane Mixture Source: Adapted from LOM, 1973

Note: Both Butane and Propane are Stored and Transported as Liquids, Liquefaction being Achieved by either Compression or Refrigeration

\subsection{Some of the Preferential Uses of the Different LPG Types are}

Propane $\mathrm{C}_{3} \mathrm{H}_{8}$ : Is a common ingredient used in bottled gas, as a high-pressure solvent, to fuel internal combustion engines, (often referred to as auto gas or auto propane). Wikipedia - Propane accessed

Commercially available "propane" fuel, or LPG, is not pure. It is at least 90\%propane with the rest mostly ethane, propylene, butane, and odorant (ethanethiol), so that people can easily smell the gas in case of a leak. Propane containing too much propene is not suited for most vehicle fuels. HD-5 (Heavy Duty-5\% maximum allowable propylene content, and no more than $5 \%$ butanes and ethane) is a specification that establishes a maximum concentration of $5 \%$ propene in propane for internal combustion engines. Although HD-5 propane was originally intended for use as vehicle fuel, it is currently being used in all propane applications. Propane is the third most popular vehicle fuel in the world, behindgasoline and diesel fuel. Propane is the third most widely used motor fuel in the world. In 2007, approximately 13 million vehicles worldwide use autogas while the 2013 estimates are that over 24.9 million vehicles are fueled by propane gas worldwide. Over 25 million tons (over 9 billion US gallons) are used annually as a vehicle fuel.LPG also has a virtual absence of sulphur, leading to cleaner burning (combustion and handling), with octane rating relatively high at 110. It is used to power some locomotives, buses, forklifts, taxis, boat motors, and backup electrical generation (figure 12) in sparsely populated areas that do not have natural gas pipelines.Propane is also used as fuel for small engines,such lawn care products likestring trimmers, lawn mowers and leaf blowers.LPG has a lower energy density per liter than either petrol or fuel-oil, so the equivalent fuel consumption is higher. 


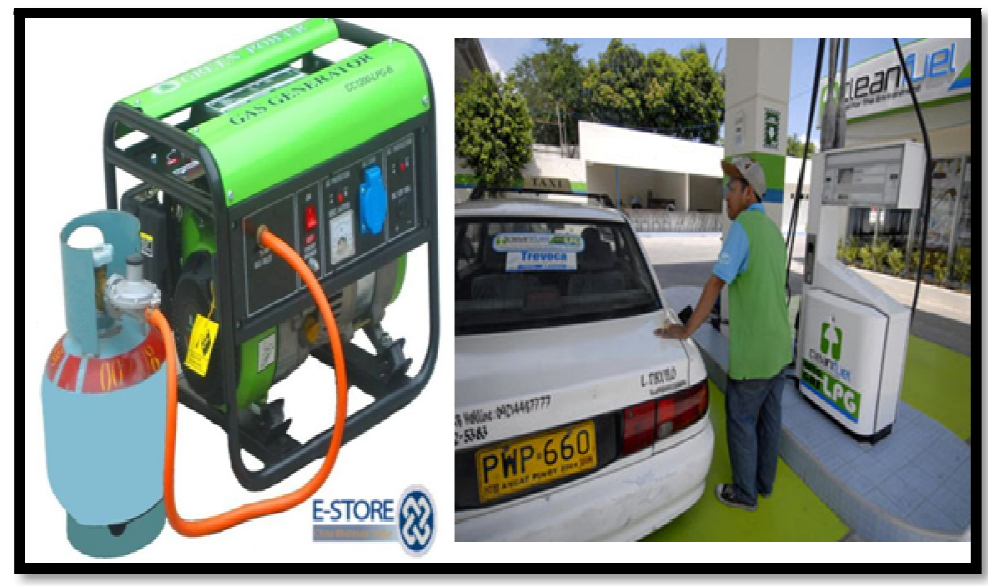

Figure 12: Use of LPG to Power Engines

Source: Adapted from Image of Uses of LPG

The other uses of propaneinclude providing off-the-grid refrigeration, as improvised explosive, as a feedstock for the production of base petrochemicals in steam cracking,in semiconductor manufacture to deposit silicon carbide, as the primary fuel for hot air balloons,as a propellant for many household aerosol sprays, including shaving creams and air fresheners.

Butane $\mathrm{C}_{4} \mathrm{C}_{10}$ : There are two butanes, normal butane containing a straight chain of carbon atoms, and iso-butane which has a branched carbon chain.

Normal butane can be used as a bottled gas, for gasoline blending, fragrance extraction solvent, either alone or in a mixture withpropane, and as a feedstock for the production of base petrochemicals in steam cracking (manufacture of ethylene andbutadiene), a key ingredient of synthetic rubber, as fuel for cigarette lighters, butane torch, butane canisters and as apropellant in aerosol sprays such as deodorants (Wikipedia - Butane), figure 13.

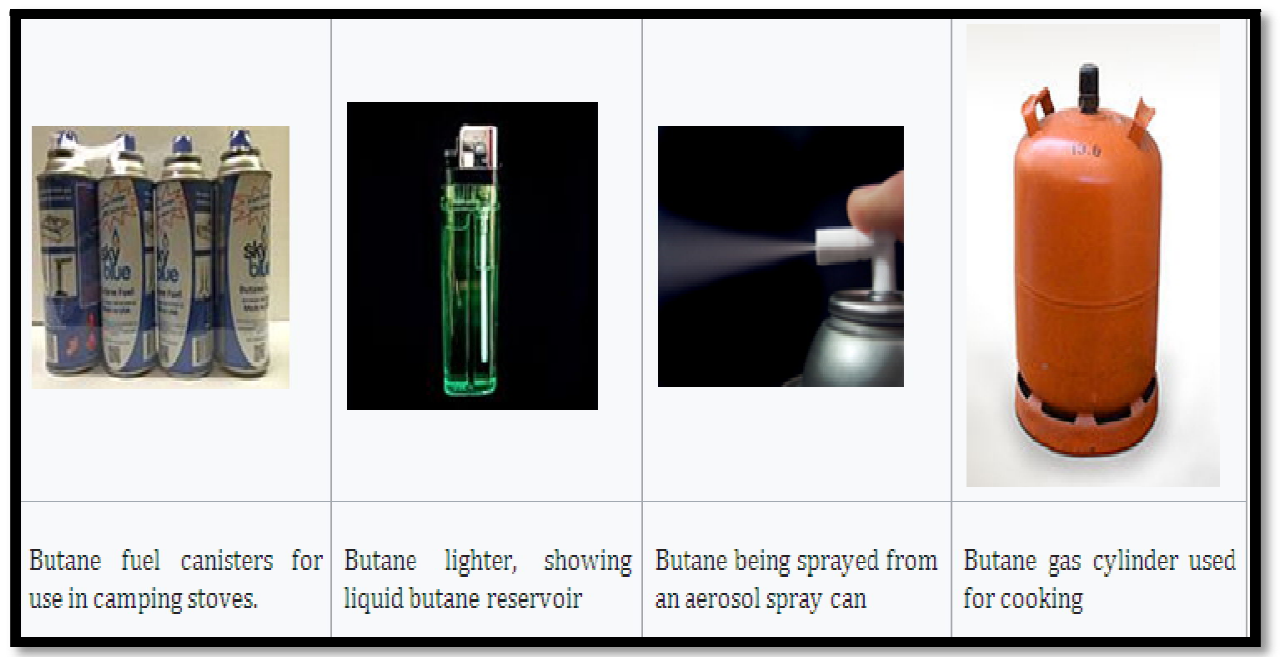

Figure 13: Some Uses of Butane LPG.

Source: Adapted from Wikipedia - Butane

Isobutane is primarily used by refineries to enhance (increase) the octane number of motor gasoline. (Wikipediaisobutane). Also, it is used as a bottled gas,refrigerant, diluent, propellant for aerosol cans and foam products, as part of blended fuel in canisters used forcamping. It is used as a raw material in the manufacture of propylene oxide, where it is oxidized to tert-butyl hydroperoxide and subsequently reacted with propylene to yield propylene oxide. The tertbutanol 1 that results as a by-product is typically used to make gasoline additives such as methyl tert-butyl ether (MTBE).

Propane $\mathrm{C}_{3} \mathrm{H}_{8}$. Butane $\mathrm{C}_{4} \mathrm{C}_{10}$ : When butane is blended with propane, it is used as a bottled gas. In some countries, the ratio of butane to propane is kept quite precise in fuel LPG. In many European countries, the propane content in LPG can be lower than 50 per cent and the LPG has been used as fuel in light duty vehicles for many years.

In Mexico, for example, gas labeled "LPG" may consist of $60 \%$ propane and $40 \%$ butane. "The exact proportion of this combination varies by country Table 5, depending on international prices, on the availability of components and, especially, on the climatic conditions that favor LPG with higher butane content in warmer regions and propane in cold areas". The warmer the country, the higher the butane content, but mostly it is $50 / 50$ and sometimes it reaching $75 \%$ butane. 


\begin{tabular}{|c|c|c|c|}
\hline Country & Propane & Butane & Propane-Butane Mixture \\
\hline Belgium & 50 & 50 & 100 \\
\hline France & 35 & 65 & 100 \\
\hline Ireland & $100^{*}$ & $100^{*}$ & 100 \\
\hline Italy & 25 & 75 & 100 \\
\hline Germany & 90 & 10 & 100 \\
\hline UK & $100^{*}$ & $100^{*}$ & 100 \\
\hline Denmark & 50 & 50 & 100 \\
\hline Greece & 20 & 80 & 100 \\
\hline Netherlands & 50 & 50 & 100 \\
\hline Spain & 30 & 70 & 100 \\
\hline Sweden & 95 & 5 & 100 \\
\hline Mexico & 60 & 40 & 100 \\
\hline Nigeria & 30 & 70 & 100 \\
\hline
\end{tabular}

Table 5: Typical Composition of LPG in \% by Volume for Different Countries

*Note: In Ireland and the U.K., LPG May be 100\% of Either Basic Gas.

Source: Http:/ / Www.Environment.Gov.Au/ Settlements/ Transport/ Composition/ Pub/ 2ch10

Pdf;Oildaddy.Com.Ng/ Articles/ Downstream/ Read/ 35/ Nigerian-LPG-Market

\section{Conclusion}

Petroleum (crude oil and natural gas) is produced from Onshore, Offshore Shallow water and Offshore Deep waters of the Niger Delta in Nigeria at depth of approximately 3,600m (12,000ft), by 5 major operators in partnership with the Nigerian National Petroleum Corporation (NNPC). On the average, about 1,000scf of associated gas is produced with every barrel of oil and $40-50 \%$ of it is flared daily.

The use of petroleum started in the "Kerosene Age" 1859-1900, when kerosene $\left(\mathrm{C}_{12}-\mathrm{C}_{16}\right)$ for lamp oil (illuminating fuel) was the only desired product from crude oil distillation. The development of Internal Combustion Engine near the beginning of the twentieth century, lead to the "gasoline age" 1900-1990, gasoline became the chief product being derived from petroleum, for transportation. The initial gasoline sold, comprised $\mathrm{C}_{3}-\mathrm{C}_{11}$ distillate from the crude oil, which resulted to rapid evaporation/ consumption in the internal combustion engine. In 1910 Dr. Walter O. Snelling an American Chemist and explosive expert with US Bureau of mines, while researching on the properties of petrol (gasoline), separated gaseous fractions from liquid ones, thus discovering the existence of propane, hence LPG.

The present petrol (gasoline)/ naphtha is comprised of $\mathrm{C}_{5}-\mathrm{C}_{11}$, and due to the strong quest for Cleaner Energy since 1990, the world is witnessing rapid transition from the "gasoline age " to the energy from $\mathrm{C}_{4}-\mathrm{C}_{1}$ hydrocarbons which might be called "LPG/ Methane Age or Methane Economy".

Nigeria started producing LPG in 1965 the premier oil refinery at Eleme in Port Harcourt and from 1965 to 2007 the Country relied on the four refineries and importation for her LPG needs. Since 2007 the bulk of LPG used in the country, come from Nigerian Liquefied Natural Gas (NLNG) Company, thus the price of LPG is hinged on the NLNG international market fundamentals, which has always maintained the retail price of $12.5 \mathrm{~kg}$ cylinder between $\$ 14$ to $\$ 18$, equivalent of $\$ 4500$ to $\$ 5500$ at the 2017 exchange rate of $\$ 1=\$ 305$. Nigeria's consumption of LPG per capita is $1.8 \mathrm{~kg}$, which is ranked the lowest in Sub-Saharan Africa compared with Ghana at 3.0kg, South Africa 5.5kg and Morocco $44 \mathrm{~kg}$.

Instead of flaring 50 per cent of the associated stranded natural gas, this investigation is focused on converting the entire flare stream to liquefied petroleum gas (LPG), i.e. propane C3 and butanes C4 mixture by cracking the C5+ fractions to C3 and $\mathrm{C} 4$ as well as reforming the $\mathrm{C} 1$ and $\mathrm{C} 2$ fractions to the $\mathrm{C} 3$ and $\mathrm{C} 4$. This implies that the proposed technique is aimed at cracking the $\mathrm{C} 5$ +fractions to the lighter molecules of $\mathrm{C} 3$ and $\mathrm{C} 4$ as well as reforming the $\mathrm{C} 1$ and $\mathrm{C} 2$ fractions to the heavier molecules of C3 and C4. LPG produced from this process would satisfy the LPG requirement of Nigeria at reduced price, creates numerous job opportunities and revenue.

The total percentage of the hydrocarbons in the typical Nigerian flare stream is $97.61 \%$, which implies that, 19,522,000 scfd of hydrocarbons are flared in a 20,000,000 scfd flare line. Using the standard conversion factor ( $1 \mathrm{scf}=$ 1.19804 moles), it becomes 23,388,136.88 moles daily (i.e. 19,522,000 x 1.19804). The apparent molecular weight of the gas mixture is $21.038 \mathrm{~g} /$ mole and assuming that $20 \%$ of the chemical energy of the entire flare stream is released as heat energy in the process, it implies that $80 \%$ of the flare stream is available for conversion to LPG daily i.e. $(492,039.624 \mathrm{x}$ $0.8)=393,631.6992 \mathrm{~kg}$ equivalent to 394 tons.

On the other hand, using mathematical conversion table ( 1 ton of LPG $=44,137.5 \mathrm{ft} 3$ of gaseous natural gas) and assuming that $20 \%$ of the chemical energy of the entire flare stream is released as heat energy in the process, the equivalent LPG weight becomes 353,840 kg, which is approximately 354 tons.

\section{References}

i. Clark, J. A., 1963. The Chronological History of the Petroleum and Natural Gas Industries. Clark Book Co., Houston, Texas, USA pp. 21-23, 30.

ii. Hadley, D. J., Turner, L., 1975. The Production of Petroleum Chemical Intermediates, In: Hobson, G. D., Pohl, W. (4th eds), Modern Petroleum Technology. Applied Science Publishers Ltd, the Institute of Petroleum, Great Britain, pp.442. 
iii. Images of what is the ratio of propane to butane in the LPG from NLNG. (Accessed 2:8:18)

iv. Images of LPG cylinder sizes (accessed 22:8:18)

v. Images of LPG gaseous expansion (accessed 22:8:18).

vi. Images of fractional products from the refinery (accessed 22:8:18)

vii. Image of uses of LPG (accessed 22:8:18).

viii. Images of syngas to alkanes (accessed 22:8:18).

ix. Images of natural gas composition (accessed 22:8:18)

x. Kings et al, 1975. Chemistry and Physics of Petroleum, In: Hobson, G. D., Pohl, W. (4th eds), Modern Petroleum Technology. Applied Science Publishers Ltd, the Institute of Petroleum, Great Britain, pp. 199, 206.

xi. Levorsen, A. I., 1967. Geology of Petroleum, W.H. Freeman and Company San Francisco. pp. 190, 177, 218.

xii. Lom, W. L., 1975. Petroleum Gases, In: Hobson, G. D., Pohl, W. (4th eds), Modern Petroleum Technology. Applied Science Publishers Ltd, the Institute of Petroleum, Great Britain, pp. 512.

xiii. NigerianLPG Market: Oil Daddy, 2017. oildaddy.com.ng/ articles/ downstream/ read/ 35/ NigerianLPG-Market. (Accessed 2:8:18).

xiv. Obosi, S; Eboh, M., 2017. Build Refineries in Nigeria, FG tells 10 Cs www.vanguardngr.com>News (accessed 8:6:17).

xv. Oilfield Review, 2003: Turning Natural Gas to Liquid.https:/ / www.slb.com>oilfield-review.

xvi. (Accessed, 25:05:17).

xvii. Okafor, P. 2015. Nigeria to rely on 75\% importation of petroleum in 2016-NNPC www.vanguardngr.com $>$ News (accessed 8:6:2017)

xviii. Uwandu, I., 2017. LPG Retail Pricing In Nigeria-Business-Nigeria-Nairaland.www.nairaland.com/ 3819923/lpgretail-g-pricing-nigeria (accessed, 3:11:17).

xix. Wikipedia. Butane.https:// en.wikipedia.org/ wiki/ butane. (Accessed, 7:11:17).

xx. Wikipedia. Propane. https:// en.wikipedia.org/ wiki/ propane. (Accessed, 7:11:17).

xxi. Wikipedia.lsobutane.https:/ / en.wikipedia.org/ wiki/ isobutane. (Accessed, 7:11:17).

xxii. Wikipedia. Steam Reforming. https:/ / en.wikipedia.org/ wiki/ steam-reforming. (Accessed22:5:17) 